\title{
Growth and endocrine function after near total pancreatectomy for hyperinsulinaemic hypoglycaemia
}

\author{
Ashraf T Soliman, Issa Alsalmi, Assim Darwish, Maurice G Asfour
}

\begin{abstract}
Seven children, with a mean (SD) age of $4 \cdot 6(2 \cdot 1)$ years, who as infants $(21(7 \cdot 5)$ days) underwent near total (95-98\%) pancreatectomy for persistent hyperinsulinaemic hypoglycaemia of infancy (PHHI) were studied. At birth all the infants were macrosomic. Four infants had been born after a difficult labour, of whom three had moderate birth asphyxia and respiratory distress. All had normal thyroid function. After surgery transient hyperglycaemia was manifest in six of the children and required insulin treatment for $5.8(3.8)$ weeks, and transient hypoglycaemia was encountered in one child and responded well to increased carbohydrate intake and diazoxide for three weeks. Six of the children rapidly crossed down their length and weight centiles during the first year after surgery. At the end of the first year these children were at or below the 5th centile of height and weight for their age and gender. After a period of $4.6(2 \cdot 1)$ years, their mean (SD) height score was $-2.57(0.5)$, growth velocity $3.9(0.75) \mathrm{cm} /$ year, and growth velocity SD score $-2 \cdot 1(0 \cdot 55) 1$ these were significantly low and denoted significant growth retardation. The growth hormone peak responses to provocation with clonidine were normal $(13.5(2 \cdot 8) \mu g / 1)$. However, the circulating insulin-like growth factor-I (IGF-I) concentrations were significantly decreased (79 (34) $\mathrm{ng} / \mathrm{ml})$. Three of the children developed diabetes at two and a half, five, and seven years after surgery, two others had impaired oral glucose tolerance and six out of the seven children had an impaired C peptide response to glucagon. Defective insulin secretion in these children might directly inhibit IGF-I synthesis in the liver. The body mass index of the pancreatectomised children was 14.9 $(0 \cdot 5)$ and was normal for age and gender; they had a normal 72 hour faecal fat content and normal serum albumin concentration. These data indicated grossly adequate exocrine pancreatic function. It appears that children requiring near total pancreatectomy for PHHI have normal developmental milestones but defective linear growth with impaired insulin secretion and low IGF-I production despite normal growth hormone response to provocation.

(Arch Dis Child 1996; 74: 379-385)
\end{abstract}

Keywords: persistent hyperinsulinaemic hypoglycaemia of infancy, growth, growth hormone, insulin-like growth factor-I.

Persistent hyperinsulinaemic hypoglycaemia of infancy (PHHI) or nesidioblastosis is a diagnosis of importance as hypoglycaemia may be exceedingly difficult to control, and associated with it is a high incidence of brain damage and subsequent mental retardation. ${ }^{12}$ In nesidioblastosis there is a continued uncontrolled proliferation of pancreatic ductular endocrine cells replacing the normal islets and infiltrating the acinar tissue. ${ }^{3}$ Unlike the gradual increase of insulin release from the normal islet cells, ${ }^{3-5}$ insulin secretion from the isolated nesidioblastosis cells is effectively autonomous. ${ }^{2}$ The hormone is released at a high rate even in the absence of secretagogues. ${ }^{6}$ Moreover, abnormalities in the distribution and number of insulin, glucagon, somatostatin, and pancreatic polypeptide cells are reported. ${ }^{78}$ Taguchi et al classified nesidioblastosis on immunohistochemical basis into diffuse and focal types which correlated to the clinical outcome. ${ }^{9}$

Infants with PHHI have excessive insulin secretion in utero, but in contrast to infants of diabetic mothers, this secretion is sustained after the neonatal period. ${ }^{7} 10$ Most cases of PHHI are sporadic and the disease is inherited as an autosomal recessive trait. ${ }^{11}$ The genetic defect responsible for the disease has recently been mapped to chromosome 11p14-15.1 by linkage analysis in 15 families. ${ }^{12}$ However, the defective gene has not yet been identified.

Diazoxide is still the mainstay of the medical management through inhibition of glucose stimulated insulin secretion. ${ }^{13-15}$ Somatostatin inhibits insulin release; however, tolerance may develop and growth hormone secretion is suppressed. ${ }^{16-18}$ The most important aim of continuous treatment, the prevention of hypoglycaemia with subsequent irreversible brain neurodevelopmental impairment, cannot be reliably avoided by conservative treatment. 1920 Therefore, surgical treatment is becoming increasingly important.

In the majority of patients surgical resection involves a subtotal (85-90\%) pancreatectomy. The reduction of hormone producing tissue resolves hyperinsulinism. ${ }^{19}$ The extent of resection continues to be controversial. The original subtotal pancreatectomy $(65 \%)$ resection $^{21}$ was attended by a $50 \%$ recurrence rate. Less than $80 \%$ resection resulted in $45 \%$ recurrence and $26 \%$ needed reoperation for persistent hypoglcaemia. ${ }^{22}$ In comparison $28 \%$ 
of patients undergoing subtotal pancreatectomy required a second operation compared with $5 \%$ of patients with $95-98 \%$ pancreatectomy. ${ }^{23}$ A primary $99 \%$ resection was performed in six patients with no recurrence. ${ }^{24} \mathrm{~A}$ $95 \%$ resection is claimed to produce the best overall results. ${ }^{25}$ Spitz et al reported short term borderline or low exocrine pancreatic function in most of the infants after $95 \%$ pancreatectomy. ${ }^{24}$ Three out of their 21 patients had evidence of steatorrhoea and two had intolerance to fatty food, whereas two children required pancreatic exocrine supplementation. However, long term exocrine pancreatic function after $95 \%$ resection appeared to be grossly normal in another study. ${ }^{26}$

While the short term utility of pancreatectomy has been established (that is, hypoglycaemia is resolved), little information is available about its long term effects. These include growth and development in relation to the endocrine and exocrine pancreatic functions. ${ }^{2728}$ To clarify this issue, we studied growth and developmental parameters and some endocrine functions of seven children who as infants underwent near total (95-98\%) pancreatectomy.

\section{Patients and methods}

Seven children, two girls and five boys, with a mean (SD) age of $4 \cdot 6(2 \cdot 1)$ years, who as infants underwent near total (95-98\%) pancreatectomy (complete resection of the tail and pancreatic head leaving less than $5 \%$ of pancreatic tissue around the common bile duct) were the subjects of this study after obtaining parents' consents. Their anthropometric data at birth (table 1) revealed significant macrosomia. Four infants had difficult labour of whom three had moderate degree of birth asphyxia (Apgar score below 7 and five minutes after birth) and respiratory distress. All had normal thyroid function. Symptomatic non-ketotic hypoglycaemia was recorded during the first 12 hours after birth with blood glucose concentrations below $1 \mathrm{mmol} / \mathrm{l}$ in all the children. The concomitant serum insulin concentration during hypoglycaemia ranged between 10 and $44 \mu \mathrm{IU} / \mathrm{ml}$ (mean $30(13.6) \mu \mathrm{IU} / \mathrm{ml}$ ) and the mean $\mathrm{C}$ peptide concentration of $7 \cdot 8 \quad(4 \cdot 3) \mu \mathrm{g} / \mathrm{l}$. Medical treatment was tried first using diazoxide $20 \mathrm{mg} / \mathrm{kg} /$ day given at eight hourly intervals, glucagon, and hydrochlorothiazide as well as continuous infusion of glucose at a rate $17-25 \mathrm{mg} / \mathrm{kg} / \mathrm{min}$. This treatment was not successful to bring up the blood glucose concentrations to $2.6 \mathrm{mmol} / \mathrm{l}$ or above. The mean age at surgery was $21(7 \cdot 5)$ days. Transient hyperglycaemia occurred in six out of the seven children after surgery and required insulin treatment for 2-11 weeks (mean 5.8 (3.8) weeks), and transient hypoglycaemia was encountered in one child which responded well to increased carbohydrate intake and diazoxide and disappeared in three weeks. Histopathology proved a diffuse nature of the lesion in five children and focal head (1) and body (1) in the other two cases.

The patients with PHHI were followed up regularly in the paediatric endocrinology clinic, Royal Hospital, Muscat, every four to six months. Twenty age matched children with insulin dependent diabetes mellitus (IDDM) and 150 age matched normal Omani children served as controls for growth data. Informed consent was obtained from the parents of all children included in the study. Each clinic visit children were examined with special emphasis on nutritional and growth data and their anthropometric measurements including weight, height, and head circumference recorded. Parents' height was recorded and midparental height calculated. Harpenden calipers and anthropometric measurements were used. The data recorded were the average of three sequential measurements determined. The height SD scores were calculated according to the formula height $\mathrm{SD}$ score $=(\mathrm{X} 1-\mathrm{X} 2) / \mathrm{SD}$, where $\mathrm{X} 2$ and $\mathrm{SD}$ are age matched population mean height and SD respectively and $\mathrm{X} 1$ is the subject height. Normal population data were according to Tanner and Whitehouse. ${ }^{29}$ The body mass index (BMI) was calculated according to the formula $\mathrm{BMI}=$ weight $(\mathrm{kg}) /$ height $\left(\mathrm{m}^{2}\right)$. The height growth velocity $\mathrm{cm} / \mathrm{year}$ was calculated for the whole year and growth velocity SD scores recorded. Dietary evaluation, both qualitative and qualitative, was assessed by the dietitian for the pancreatectomised children using the recall method. The growth data of the three children who developed IDDM were recorded for a year after starting insulin treatment. Developmental assessment was carried on every six months. This included evaluation of the gross motor, manipulation (fine motor), speech/language, general understanding, and miscellaneous abilities according to Illingworth. ${ }^{30} 31$ The visual-motor assessment

Table 1 Anthropometric data of children with PHHI before and after pancreatectomy

\begin{tabular}{|c|c|c|c|c|c|c|c|c|c|c|c|c|c|c|c|c|c|c|c|c|}
\hline \multirow[b]{2}{*}{$\begin{array}{l}\text { Patient } \\
\text { No }\end{array}$} & \multirow[b]{2}{*}{ Sex } & \multicolumn{4}{|l|}{ At birth } & \multicolumn{4}{|c|}{ First year } & \multicolumn{4}{|c|}{ Second year } & \multicolumn{6}{|c|}{ Last visit } & \multirow[b]{2}{*}{$\begin{array}{l}\text { Midparental } \\
\text { height SD } \\
\text { score }\end{array}$} \\
\hline & & $\begin{array}{l}\text { Weight } \\
(\mathrm{kg})\end{array}$ & $\begin{array}{l}\text { Length } \\
(\mathrm{cm})\end{array}$ & $\begin{array}{l}S D \\
\text { score }\end{array}$ & $\begin{array}{l}\text { Head } \\
\text { circumference } \\
(\mathrm{cm})\end{array}$ & $\begin{array}{l}\text { Weight } \\
\text { (kg) }\end{array}$ & $\begin{array}{l}\text { Length } \\
(\mathrm{cm})\end{array}$ & $\begin{array}{l}S D \\
\text { score }\end{array}$ & $\begin{array}{l}\text { Head } \\
\text { circumference } \\
(\mathrm{cm})\end{array}$ & $\begin{array}{l}\text { Weight } \\
\text { (kg) }\end{array}$ & $\begin{array}{l}\text { Height } \\
(\mathrm{cm})\end{array}$ & $\begin{array}{l}S D \\
\text { score }\end{array}$ & $\begin{array}{l}\text { Head } \\
\text { circumference } \\
(\mathrm{cm})\end{array}$ & $\begin{array}{l}\text { Age } \\
\text { (years) }\end{array}$ & $\begin{array}{l}\text { Weight } \\
(\mathrm{kg})\end{array}$ & $\begin{array}{l}\text { Height } \\
(\mathrm{cm})\end{array}$ & $\begin{array}{l}S D \\
\text { score }\end{array}$ & $\begin{array}{l}B M I \\
\left(\mathrm{~kg} / \mathrm{m}^{2}\right)\end{array}$ & $\begin{array}{l}\text { B cell } \\
\text { response }\end{array}$ & \\
\hline 1 & $\mathbf{M}$ & $5 \cdot 1$ & 54 & 1.56 & 35 & $7 \cdot 7$ & $70 \cdot 8$ & -1.94 & 43.3 & 8.7 & $78 \cdot 1$ & -2.8 & $47 \cdot 5$ & 2.5 & $9 \cdot 2$ & $80 \cdot 2$ & -2.87 & $14 \cdot 4$ & IDDM & -0.4 \\
\hline 2 & $\mathbf{M}$ & $4 \cdot 7$ & 53 & $1 \cdot 1$ & 36 & $7 \cdot 6$ & $71 \cdot 3$ & -1.75 & $44 \cdot 2$ & 8.5 & $77 \cdot 8$ & -2.9 & $46 \cdot 8$ & 3.5 & $11 \cdot 1$ & $86 \cdot 3$ & $-3 \cdot 25$ & 14.9 & IGT, LCP & -0.25 \\
\hline 3 & $\mathbf{M}$ & 4.35 & 53 & $1 \cdot 1$ & 34 & 8.05 & 68.4 & $-2 \cdot 82$ & 42.5 & $9 \cdot 6$ & 79.9 & $-2 \cdot 26$ & 46.2 & 3 & 11.7 & 85.5 & -2.54 & 16 & IGT, LCP & 0.35 \\
\hline 4 & $\mathbf{M}$ & 4.8 & 51 & 0.2 & 35 & $10 \cdot 1$ & $77 \cdot 6$ & 0.55 & $45 \cdot 2$ & 12 & $87 \cdot 3$ & -0.1 & $48 \cdot 2$ & $4 \cdot 25$ & $14 \cdot 3$ & $\mathbf{9 8 . 1}$ & -1.58 & $14 \cdot 8$ & NL & 0.8 \\
\hline 5 & $\mathbf{M}$ & $4 \cdot 45$ & 49 & -0.6 & 36 & $8 \cdot 3$ & $69 \cdot 5$ & $-2 \cdot 42$ & $44 \cdot 7$ & $9 \cdot 3$ & $78 \cdot 4$ & $-2 \cdot 71$ & 47.6 & $3 \cdot 25$ & 11.3 & 86.5 & -2.76 & $15 \cdot 1$ & LCP & $-0 \cdot 18$ \\
\hline 7 & $\mathbf{F}$ & $4 \cdot 7$ & 51 & 0.5 & 36 & $8 \cdot 2$ & $68 \cdot 4$ & $-2 \cdot 1$ & $45 \cdot 5$ & $9 \cdot 3$ & 76.9 & -2.96 & $47 \cdot 8$ & 7 & $17 \cdot 3$ & $108 \cdot 5$ & $-2 \cdot 28$ & $14 \cdot 7$ & IDDM & 0.85 \\
\hline $\begin{array}{l}\text { Mean } \\
S D\end{array}$ & & $\begin{array}{l}4 \cdot 6 \\
0.3\end{array}$ & $\begin{array}{l}52 \\
1.6\end{array}$ & $\begin{array}{l}0.79 \\
0.47\end{array}$ & $\begin{array}{l}35 \\
0.7\end{array}$ & $\begin{array}{l}8 \cdot 24 \\
0 \cdot 76\end{array}$ & $\begin{array}{c}70 \cdot 7 \\
2.98\end{array}$ & $\begin{array}{l}-2 \\
0.69\end{array}$ & $\begin{array}{c}44 \cdot 4 \\
1.02\end{array}$ & $\begin{array}{l}9 \cdot 4 \\
1\end{array}$ & $\begin{array}{c}79.5 \\
3.31\end{array}$ & $\begin{array}{r}-2.35 \\
0.94\end{array}$ & $\begin{array}{c}47.4 \\
0.61\end{array}$ & $\begin{array}{l}4.07 \\
1 \cdot 4\end{array}$ & $\begin{array}{c}12 \cdot 6 \\
2 \cdot 44\end{array}$ & $\begin{array}{r}91 \cdot 8 \\
9 \cdot 2\end{array}$ & $\begin{array}{r}-2.57 \\
0.49\end{array}$ & $\begin{array}{r}14.88 \\
0.52\end{array}$ & & $\begin{array}{l}0.53 \\
0.27\end{array}$ \\
\hline
\end{tabular}

$\star_{\mathrm{IGT}}=$ impaired glucose tolerance, $\mathrm{LCP}=$ low $\mathrm{C}$ peptide response to glucagon, $\mathrm{NL}=$ normal. $\mathrm{C}$ peptide response and glucose tolerance. 
included Gesell figures ${ }^{32}$ and the GoodenoughHarris draw a person tests. ${ }^{33}$ The bone age was determined according to Greulich and Pyle atlas. ${ }^{34}$ Glycated haemoglobin concentrations were estimated every six months.

Pancreatectomised children were investigated for their endocrine status. On the morning of the test a fasting (eight hour overnight fast) venous blood sample was obtained for determination of complete blood count and serum albumin, bilirubin, alanine aminotransferase, alkaline phosphatase, calcium, phosphorus, and bicarbonate concentrations. The serum was separated from the formed elements by centrifugation and kept frozen at $-20^{\circ} \mathrm{C}$ until analysed for growth hormone, free thyroxine, thyroid stimulating hormone, and insulin-like growth factor-I (IGF-I). An oral dose of clonidine $\left(0.15 \mathrm{mg} / \mathrm{m}^{2}\right)$ and intravenous dose of $0.5 \mathrm{mg}$ tetracosactrin (Synacthen, Ciba) were given and blood samples were collected every 30 minutes for two hours for determination of growth hormone and cortisol concentrations. Human growth hormone and IGF-I were measured by radioimmunometric assay, employing reagents purchased from the Nichols Institute (San Juan Capistrano, CA, USA). Intra-assay coefficient of variation averaged 5.5 in the range of growth hormone values detected and $8.7 \%$ in the range of IGF-I concentration measured. Free thyroxine, thyroid stimulating hormone, and cortisol concentrations were measured using Amerlex-RIA kits (Kodak Clinical Diagnostics). Glycated haemoglobin was measured by the IMx glycated haemoglobin assay (a boronate affinity binding assay) kits (Abbot Laboratory Diagnostic Division). The normal range for the non-diabetic population is $4 \cdot 4-6 \cdot 4 \%$. After three days on full carbohydrate diet and after an overnight fast, an oral glucose tolerance test was performed $(1.75 \mathrm{~g}$ glucose/kg body weight) and serum glucose estimated by glucose oxidase method before and one and two hours after the oral glucose load. On the second morning serum $\mathrm{C}$ peptide was determined before and six minutes after intravenous injection of $15 \mu \mathrm{g} / \mathrm{kg}$ glucagon. Exocrine pancreatic function was assessed by 72 hour stool fat estimation.

Statistical analyses were done using the

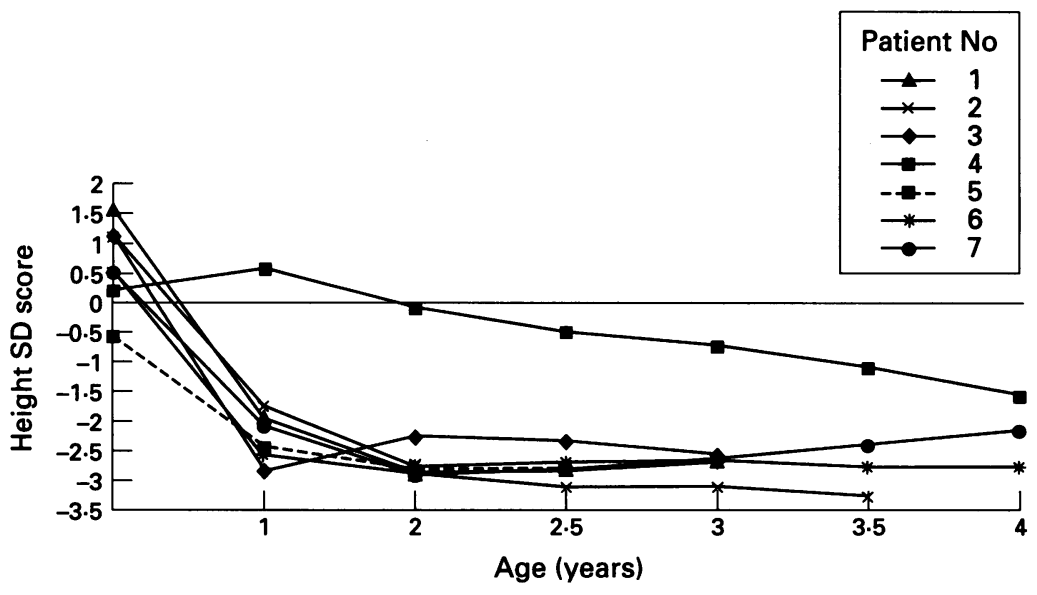

Height SD score after pancreatectomy for PHHI. unpaired $t$ test to compare mean analyte concentrations among the study groups when data were normally distributed and Wilcoxon test when they were not. Statistical significance was accepted at $\mathrm{p}<0 \cdot 05$. Data are presented as mean (SD).

\section{Results}

Table 1 summarises the anthropometric data of patients and controls. Despite their large size at birth, six out of the seven children with PHHI crossed down growth centiles for length and weight during the first year after pancreatectomy to be at the 5th centile or below. After $4.6(2 \cdot 1)$ years of follow up their height SD score was significantly low at $-2.57(0.5)$ denoting statural growth impairment (figure) and significantly lower than midparental height SD score. Their mean annual growth velocity (3.9 $(0.75) \mathrm{cm} /$ year and growth velocity $\mathrm{SD}$ score $(-2 \cdot 1(0.55))$ were significantly low. Their mean BMI at $14.88(0.6)$ was not different from those for the healthy controls, $15 \cdot 8(0 \cdot 4)$.

Developmental evaluation, at a mean age of $4.6(2 \cdot 1)$ years, revealed that only one child had mild mental retardation with delayed motor and language development. The other six patients had normal gross and fine motor development. Their language development and cognitive function were appropriate for their age.

Table 2 represents growth data of pancreatectomised children in comparison with 20 children with IDDM and 150 normal children followed up for one year. The height SD score, annual growth velocity, and growth velocity SD score of pancreatectomised patients as well as their circulating IGF-I concentrations were significantly lower than those for children with IDDM and for the laboratory normal range for healthy children between 1-6 years $(195(37 \cdot 5)$ $\mathrm{ng} / \mathrm{ml}$ ). The glycated haemoglobin concentrations were significantly higher in the pancreatectomised and IDDM groups compared with the normal range of the laboratory data for children between 1-6 years $(4 \cdot 6(0 \cdot 5) \%)$.

At the age of $4.6(2 \cdot 1)$ years all children with PHHI had normal haemogram and hepatic, renal, and thyroid functions. Serum albumin concentrations did not differ between patients $(41(5 \cdot 2) \mathrm{g} / \mathrm{l})$ and controls $(42.5(6 \cdot 3) \mathrm{g} / \mathrm{l})$. Growth hormone peak response to clonidine provocation $(13.5(2.8) \mu \mathrm{g} / \mathrm{l})$ was appropriate in all pancreatectomised children. Their basal (3.95 (0.59) $\mathrm{nmol} / \mathrm{l})$ and tetracosactrin provoked (845 (245) nmol/1) serum cortisol concentrations were normal. An oral glucose tolerance test showed a diabetic curve in three and impaired glucose tolerance in two out of the seven patients. The other two children had normal glucose tolerance. However the $C$ peptide response to intravenous glucagon was impaired in six out of the seven patients (table 3). Despite a history of intolerance to fatty meals in two out of the seven patients, exocrine pancreatic function as assessed by 72 hour stool collection was within the normal range (mean fat $6 \cdot 1(0.6) \mathrm{g} /$ day; normal 2-7 g/day). 
Table 2 Growth data of pancreatectomised children compared with normal children and those with IDDM; values are mean (SD)

\begin{tabular}{|c|c|c|c|c|c|c|c|c|}
\hline Groups & $\begin{array}{l}\text { Age } \\
\text { (years) }\end{array}$ & $\begin{array}{l}\text { Height } \\
S D \\
\text { score }\end{array}$ & $\begin{array}{l}\text { Growth } \\
\text { velocity } \\
\text { (cm/year) }\end{array}$ & $\begin{array}{l}\text { Growth } \\
\text { velocity } \\
\text { SD score }\end{array}$ & $\begin{array}{l}B M I \\
\left(\mathrm{~kg} / \mathrm{m}^{2}\right)\end{array}$ & $\begin{array}{l}\text { Glycated } \\
\text { haemoglobin } \\
(\%)\end{array}$ & $\begin{array}{l}I G F-I \\
(n g / m l)\end{array}$ & $\begin{array}{l}\text { Bone age } \\
\text { delay } \\
\text { (years) }\end{array}$ \\
\hline $\begin{array}{l}\text { IDDM }(n=20) \\
\text { Normal }(n=150) \\
\text { Pancreatectomised }(n=7)\end{array}$ & $\begin{array}{l}5 \cdot 7(2 \cdot 6) \\
6 \cdot 3(1 \cdot 7) \\
4 \cdot 6(2 \cdot 1)\end{array}$ & $\begin{array}{l}1.5(0.45)^{\star} \\
0.39(0.12) \\
2.57(0.50)\end{array}$ & $\begin{array}{l}5 \cdot 3(0 \cdot 12)^{\star} \\
6.6(0 \cdot 16) \\
3.9(0.75)^{\star}\end{array}$ & $\begin{array}{l}0.85(0.28) \\
0.21(0.04) \\
2 \cdot 10(0.55)^{\star}\end{array}$ & $\begin{array}{l}15.6(0.38) \\
15.8(0.43) \\
14.9(0.50)^{\star}\end{array}$ & $\begin{array}{l}8 \cdot 25(1 \cdot 2)^{\star} \\
4 \cdot 6(0 \cdot 5) \dagger \\
6 \cdot 1(1 \cdot 5)^{\star}\end{array}$ & $\begin{array}{l}142(53) \\
195(37) \dagger \\
79(34)\end{array}$ & $\begin{array}{l}1.45(0.21) \\
\text { ND } \\
1.20(0.35)^{\star}\end{array}$ \\
\hline
\end{tabular}

$\mathrm{ND}=$ not done.

${ }^{\star} \mathrm{p}<0.05 \mathrm{IDDM} /$ pancreatectomised groups $v$ normal children.

tNormal laboratory data for children between $1-6$ years.

\section{Discussion}

At birth the macrosomia and the physical appearance of infants with PHHI resembled those of infants of diabetic mothers. Two out of the seven infants had cardiomegaly, three had hepatomegaly and the other four developed hepatic enlargement during the first few days after birth. These manifestations reflected the growth promoting effect of intrauterine hyperinsulinaemia. Antenatal diagnosis of fetal hyperinsulinaemia can be made by measuring liquor insulin concentrations or by cordocentesis. ${ }^{35} 36$ Intrauterine macrosomia can be predicted by ultrasonic evaluation of different fetal anthropometric parameters. ${ }^{37} 38$

Despite macrosomia at birth, six out of the seven infants rapidly crossed down growth centiles for length and weight. By the end of the first year their length and weight was at or below the 5 th centiles for age and gender. The endocrine control of growth in utero is quite different from that after birth. Major growth promoting hormones such as growth hormone, thyroxine, and sex steroids have almost no influence on fetal growth. ${ }^{39}$ In contrast, insulin is essential for fetal growth by acting as mitogen on embryonic tissues ${ }^{40}$ and via stimulation of tissue IGF-I release. ${ }^{41}$ IGF-I controls organ growth and functional differentiation during fetal growth. ${ }^{42} 43$ These facts explain macrosomia in our children with nesidioblastosis as well as in infants of diabetic mothers. However, after birth dramatic changes occur with the appearance of a quite different physiology. Circulating insulin concentration declines, and IGF-I secretion becomes growth hormone dependent and less dependent on insulin. ${ }^{39} 44$ These changes, in addition to the switch off hyperinsulinism, with or without

Table 3 Laboratory data of pancreatectomised children and normal children; values are mean (SD)

\begin{tabular}{|c|c|c|}
\hline & $\begin{array}{l}\text { Pancreatectomised } \\
\text { children } \\
(n=7)\end{array}$ & $\begin{array}{l}\text { Normal } \\
(n=10)\end{array}$ \\
\hline Free thyroxide $(\mathrm{pmol} / \mathrm{l})$ & $14 \cdot 5(2 \cdot 0)$ & $14 \cdot 6(1 \cdot 5)$ \\
\hline $\begin{array}{l}\text { hormone (mIU/l) } \\
\text { Growth hormone }(\mu \mathrm{g} / \mathrm{l})\end{array}$ & $1.03(0.25)$ & $1.60(0.05)$ \\
\hline $\begin{array}{l}\text { Basal } \\
\text { Peak } \\
\text { IGF-I (ng/ml) }\end{array}$ & $\begin{array}{l}1.50(0.45) \\
13.5(2 \cdot 8) \\
79(34)^{\star}\end{array}$ & $\begin{array}{c}1 \cdot 20(0 \cdot 2) \\
15 \cdot 4(0 \cdot 9) \\
195(38)\end{array}$ \\
\hline Cortisol (nmol/1) & & \\
\hline $\begin{array}{l}\text { Basal } \\
\text { Peak }\end{array}$ & $\begin{array}{l}395(59) \\
845(245)\end{array}$ & $\begin{array}{l}498(135) \\
965(210)\end{array}$ \\
\hline $\begin{array}{l}\text { C peptide }(\mathrm{ng} / \mathrm{ml}) \\
0 \mathrm{Min} \\
6 \mathrm{Min}\end{array}$ & $\begin{array}{l}0.65(0.35)^{\star} \\
1.05(0.50)^{\star}\end{array}$ & $\begin{array}{l}1.9(0.6) \\
4.6(0.5)\end{array}$ \\
\hline $\begin{array}{l}\text { Glucose }(\mathrm{mmol} / \mathrm{l}) \\
0 \text { Hours } \\
2 \text { Hours } \\
\text { Albumin }(\mathrm{g} / \mathrm{l})\end{array}$ & $\begin{array}{l}7 \cdot 4(1 \cdot 8)^{\star} \\
9 \cdot 0(3 \cdot 6)^{\star} \\
41 \cdot 0(5 \cdot 2)\end{array}$ & $\begin{array}{r}4 \cdot 3(0 \cdot 5) \\
6 \cdot 2(0 \cdot 9) \\
42 \cdot 5(6 \cdot 3)\end{array}$ \\
\hline
\end{tabular}

${ }^{\star} \mathrm{p}<0.05$. hypoinsulinaemia, after pancreatectomy might explain in part the rapid deceleration of growth in our children with PHHI during the first year after surgery. In support of this view, all our patients (numbers 2, 3, and 5) who were evaluated during the first year after surgery had impaired glucose tolerance and defective $\mathrm{C}$ peptide release after glucagon (peak $\mathrm{C}$ peptide $0.3,0.68$, and $0.85 \mathrm{ng} / \mathrm{ml}$ respectively). The possibility of compromised nutrition due to defective exocrine pancreatic secretion, especially during the few months after surgery, and its negative effect on IGF-I synthesis cannot be ruled out. ${ }^{24}$

Infants of diabetic mothers who do not have exocrine pancreatic deficiency also show catchdown growth in the first year of life. ${ }^{45}$ In these infants poor feeding is a major problem that is often present and might be an important factor contributing to slowing of growth in these infants. ${ }^{46}$ Moreover, after major surgery the protein catabolic status might adversely affect growth especially during infancy. Recently this catabolic status has been prevented by administration of growth hormone/IGF-I treatment. ${ }^{47} 48$

Dietary assessment during the first year after surgery, using the recall method for three days, revealed that six out of the seven infants had a normal appetite and consumed an adequate amount of milk and other food items (cereals, egg, vegetables, and meat $/ \mathrm{kg}$ ). Only one infant had severe anorexia and poor weight gain after the operation that necessitated gavage feeding for 10 days and pancreatic extract supplementation for eight weeks. During childhood they had grossly normal exocrine pancreatic function evidenced by normal 72 hour faecal fat excretion and their dietary intake was qualitatively and quantitatively normal. However, two children had a history of intolerance to dietary fat.

At a mean age of $4.6(2 \cdot 1)$ years height SD score, growth velocity, and growth velocity $S D$ score were significantly low. Decreased IGF-I synthesis in these children can explain in part their impaired statural growth. IGF-I production is regulated mainly by growth hormone, ${ }^{49}$ but other hormones including insulin as well as the nutritional status contribute to this regulation.5051 Despite the possibility of ischaemic/hypoxic insult to the hypothalamicpituitary axis during difficult labour and/or one or more of the hypoglycaemic seizure attacks, our patients have a proper growth hormone response to clonidine provocation, thus ruling out growth hormone deficiency. Their low basal and glucagon provoked $\mathrm{C}$ peptide 
Table 4 Growth data of the three diabetic children before and after insulin treatment

\begin{tabular}{|c|c|c|c|c|c|c|c|c|}
\hline \multirow[b]{2}{*}{$\begin{array}{l}\text { Patient } \\
\text { No }\end{array}$} & \multicolumn{4}{|c|}{ Before insulin } & \multicolumn{4}{|c|}{ After insulin } \\
\hline & $\begin{array}{l}\text { Age } \\
\text { (years) }\end{array}$ & $\begin{array}{l}\text { Height } \\
\text { SD score }\end{array}$ & $\begin{array}{l}\text { Growth } \\
\text { velocity }\end{array}$ & $B M I$ & $\begin{array}{l}\text { Age } \\
\text { (years) }\end{array}$ & $\begin{array}{l}\text { Height } \\
\text { SD score }\end{array}$ & $\begin{array}{l}\text { Growth } \\
\text { velocity }\end{array}$ & $B M I$ \\
\hline $\begin{array}{l}1 \\
6 \\
7\end{array}$ & $\begin{array}{l}2 \cdot 5 \\
5 \\
7\end{array}$ & $\begin{array}{l}-2 \cdot 87 \\
-2 \cdot 77 \\
-2 \cdot 28\end{array}$ & $\begin{array}{l}4 \cdot 9 \\
3 \cdot 8 \\
4 \cdot 3\end{array}$ & $\begin{array}{l}14 \cdot 4 \\
13 \cdot 4 \\
14 \cdot 7\end{array}$ & $\begin{array}{l}3 \cdot 5 \\
6 \\
8\end{array}$ & $\begin{array}{l}-2 \cdot 68 \\
-2 \cdot 6 \\
-2 \cdot 1\end{array}$ & $\begin{array}{l}8 \\
6 \cdot 1 \\
7 \cdot 7\end{array}$ & $\begin{array}{l}15 \cdot 7 \\
15 \cdot 3 \\
15 \cdot 1\end{array}$ \\
\hline $\begin{array}{l}\text { Mean } \\
\text { SD }\end{array}$ & $\begin{array}{l}4 \cdot 8 \\
1 \cdot 8\end{array}$ & $\begin{array}{r}-2 \cdot 64 \\
0 \cdot 25\end{array}$ & $\begin{array}{l}4 \cdot 3 \\
0 \cdot 45\end{array}$ & $\begin{array}{c}14 \cdot 2 \\
0 \cdot 56\end{array}$ & $\begin{array}{l}5 \cdot 8 \\
1 \cdot 8\end{array}$ & $\begin{array}{r}-2.46 \\
0.26\end{array}$ & $\begin{array}{l}7 \cdot 3^{\star} \\
0 \cdot 83\end{array}$ & $\begin{array}{r}15 \cdot 5 \\
0 \cdot 2\end{array}$ \\
\hline
\end{tabular}

${ }^{\star} \mathrm{p}<0.05$ before $v$ after insulin treatment.

concentrations (6/7) and the high incidence of impaired glucose tolerance (2/7) and diabetes (3/7) denote a state of hypoinsulinism that can impair hepatic IGF-I production. ${ }^{52} 53$ Moreover, insulin plays an important part in determining the bioavailability of IGF-I through its action on insulin-like growth factor binding protein-I (IGFBP-I). Therefore, defective insulin secretion can increase hepatic production of IGFBP-I leading to decreased bioavailability of IGF-I. ${ }^{53}$ In support of this view our patient (4), who experienced transient hypoglycaemia after surgery and had normal glucose tolerance and normal $\mathrm{C}$ peptide release after glucagon, had better linear growth than those with impaired glucose tolerance and/or defective $\mathrm{C}$ peptide release. Moreover, after one year of insulin treatment in the three children who developed IDDM, the growth velocity and height SD score improved significantly (table 4). In agreement with our findings, Glaser et al noted the occurrence of diabetes at puberty in children who underwent partial pancreatectomy as neonates. ${ }^{54}$ Although other studies reported normal pancreatic endocrine function along with ultrasonographic evidence of extensive regeneration of the pancreas after resection, 2855 in these studies the follow up period was too short to allow detection of late pancreatic abnormalities. However, the fact that control children with IDDM and higher glycated haemoglobin concentrations had better linear growth and significantly higher levels of circulating IGF-I compared with our pancreatectomised children denotes that other factors might contribute to their growth impairment. The normal BMI, serum albumin, and faecal fat concentrations and adequate dietary intake in all the pancreatectomised children indicate adequate exocrine pancreatic function and exclude any significant contribution of malabsorption and/or malnutrition in the production of their growth impairment and low IGF-I production.

Whereas the exocrine tissue grew adequately enough to prevent the development of significant malabsorption, the growth of the endocrine tissue was inadequate to maintain long term normal glycaemic control ( $3 / 7$ with IDDM, 2/7 with impaired glucose tolerance, and $6 / 7$ with impaired $C$ peptide response to glucagon). The deterioration of glucose homeostasis seems to be progressive, as demonstrated in two of our children who had defective $C$ peptide release and impaired glucose tolerance at seven and nine months after surgery and developed diabetes at the age of 2.5 and 5 years respectively. In support of our findings, Brockenbrough et al described discordance of exocrine and endocrine growth after $90 \%$ pancreatectomy in rats, ${ }^{56}$ and Bonner-Weir et al demonstrated defective glucose induced insulin release in rats after pancreatic regrowth after partial pancreatectomy. 57

Leibowitz et al reported the occurrence of overt diabetes during puberty in six out of eight patients who underwent subtotal pancreatectomy as infants for PHHI. ${ }^{58}$ By comparing their results with ours it appears that near total pancreatectomy, a more extensive procedure, is followed by early onset of diabetes as the regrowth of the remaining $\beta$ cell mass was adequate to maintain normal glycaemic control for only a few years (2-7) after surgery. Moreover, it is still questioned whether $\beta$ cell failure is the natural end stage of PHHI, with the onset of diabetes being hastened by partial pancreatectomy and its extent. ${ }^{58}$

Several authors have stressed the high incidence of mental retardation in children with PHHI, which is related to the delay in making the diagnosis and extreme difficulty experienced in controlling the hypoglycaemia. ${ }^{59-62}$ Developmental parameters, including motor, cognitive and language, were appropriate for age in six out of the seven patients. ${ }^{63}$ This could be explained on the basis of early diagnosis and early and extensive surgical management of our patients. However, one child has mild mental retardation, delay in both motor and language development, and grand mal epilepsy. Computed tomography of his brain at the age of 3 days revealed moderately dilated ventricles, wide cerebrospinal fluid spaces, and generalised low density involving all the cortical lobes. Repeated computed tomography of his brain at the age of 10 weeks, six weeks after pancreatectomy, showed deep cortical sulci and dilated ventricles consistent with cerebral atrophy. These early brain changes might be explained by his low Apgar score at zero and five minutes ( 4 and 6 respectively) and/or by his severe and early hypoglycaemia. Experimental designs showed that energy failure and loss of ion homoeostasis during hypoglycaemia are associated with cessation of electroencephalographic activity, which is followed by neuronal damage. ${ }^{63}$ The incrimination of a subtype of excitatory amino acid receptor, the $N$-methyl-Daspartate (NMDA) receptor, in the pathogenesis of hypoglycaemia induced selective neuronal necrosis ${ }^{64-68}$ and the demonstrated usefulness of NMDA antagonists to prevent neuronal necrosis during hypoglycaemia, 6970 impose the possibility of pharmacotherapeutic intervention. ${ }^{71-73}$

In summary, in children who undergo near total pancreatectomy for PHHI the regrowth of the $\beta$ cell mass appears to be inadequate for maintaining long term glycaemic control, with a high incidence of impaired glucose tolerance and IDDM during childhood. This defective insulin secretion appears to be an important cause of their impaired statural growth; however, their neurodevelopmental outcome is satisfactory. 
1 Thomas CG, Underwood MD, Carney CN. Neonatal infantile hypoglycemia due to insulin excess. Ann Surg 1977; 185: 505-7.

2 Aynsley-Green A, Polak JM, Bloom SR, et al. Nesidioblastosis of the pancreas: definition of the syndrome and the management of severe neonatal hyperinsulinaemic hypoglycaemia. Arch Dis Child 1981; 56: sulinaemic

3 Aynsley-Green A. Nesidioblastosis of the pancreas in infancy. Dev Med Child Neurol 1981; 23: 372-9.

4 Ashcroft SJH. The control of insular release by sugars. Ciba Found Symp 1976 (new series); 41: 117-39.

5 Ashcroft SJH, Bunvce J, Lowry M, Hansen SE, Hedeskov CJ. The effect of sugar on (pro)insulin biosynthesis. Biochem $\mathcal{1}$ 1978; 174: 517-26.

6 Kaiser N, Corcos AP, Tur-Sinai A, et al. Regulation of insulin release in persistent hyperinsulinemic hypoglycemia of infancy studied in long-term culture of pancreatic tissue Diabetologia $1990 ; 33$ : 482-8.

7 Heitz PU, Kloppel G, Hachi WH. Nesidioblastosis: the pathologic basis of persistent hyperinsulinemic hypopathologic basis of persistent hyperinsulinemia in infants. Diabetes 1977; 26: 632-6.

8 Polak JM, Bloom SR. Somatostatin deficiency in persistent neonatal hyperinsulinaemic hypoglycaemia. In: Marks V, Andreani D, eds. Current views on hypoglycaemia and glucagon. London: Academic Press, 1980: 367-78.

9 Taguchi T, Suita-S, Hirose R. Histological classification of nesidioblastosis: efficacy of immunohistochemical study of neuron-specific enolase. $\mathcal{F}$ Pediatr Surg 1991; 26: 740-4.

10 Molsted-Pedersen L. Aspects of carbohydrate metabolism in newborn infants of diabetic mothers, II. Neonatal changes in k values. Acta Endocrinol (Copenh) 1972; 69: 189-98.

11 Woolf DA, Leonard JV, Trembath RC, Pembrey ME, Grant DB. Nesidioblastosis: evidence for autosomal
recessive inheritance. Arch Dis Child 1991; 66: 529-30.

12 Glaser B, Chin KC, Anker R. Familial hyperinsulinism maps to chromosome $11 \mathrm{p} 14-15.130 \mathrm{cM}$ centromeric to the insulin gene. Nature Genetics 1994; 7: 185-8.

13 Grant DB, Dunger DB, Burns EC. Long-term treatment with diazoxide in childhood with hyperinsulinism. Acta Endocrinol (Copenh) 1986; 279: 340-5

14 Goodman HC, Morishima A, Grumbach MM, Kaplan SL. The use of diazoxide in hypoglycemia in childhood. Ann NY Acad Sci 1968; 150: 367-72.

15 Coombs JT, Grunt JA, Brandt IK. Hematologic reaction of diazoxide. Pediatrics 1967; 40: 90-2.

16 Kirk JM, Di Silvio L, Hindmarsh PC, Brook CG. Somatostatin analogue in the short term management of hyperinsulinism. Arch Dis Child 1988; 63: 1493-4.

17 Hawdon JM, Ward Platt MP, Lamb WH, Aynsley-Green A. Tolerance to somatostatin analogue in a preterm infant with islet cell dysregulation syndrome. Arch Dis Child 1991; 66: 341-3.

18 Rodriguez A, Del-Pozo E, Rodriguez-Arnao MD, Gomez-Pan A. Growth progression and 24-hour hormone profile in an infant treated chronically with a long-
acting somatostatin derivative. Horm Res 1991; 35: 217-21.

19 Willberg B, Muller E. Surgery for nesidioblastosis, indications, treatment and results. Prog Pediatr Surg 1991; 26: 76-83.

20 Dohrmann P, Mengel W, Splieth J. Total pancreatectomy in a case of nesidioblastosis due to persisting hyper-
insulinism following subtotal pancreatectomy. Prog insulinism following subto

21 Gross RE. The surgery of infancy and childhood. Philadelphia: W B Saunders, 1953 .

22 Martin LW, Ryckman FC, Sheldon CA. Experience with $95 \%$ pancreatectomy and splenic salvage for neonatal nesidioblastosis. Ann Surg 1984; 200: 355-62.

23 Thomas CG, Guenca RE, Azizkhan RG. Changing concepts of islet dysplasia in neonatal and infantile hyperinsulinism. World 7 Surg 1988; 12: 598-609.

24 Spitz L, Bhargava RK, Grant DB, Leonard JV. Surgical treatment of hyperinsulinaemic hypoglycaemia in infancy treatment of hyperch Dis Child 1992; 67: 201-5.

25 Spitz L, Buick RG, Grant DB. Surgical treatment of nesidioblastosis. Pediatric Surgery International 1986; 1: $26-9$.

26 Rother IK, Matsumoto SM, Rasmussen NH, Schwenk F. Long-term follow-up of children who underwent subtotal pancreatectomy as infants for hyperinsulinemic hypoglycemia. Pediatr Res 1994; 35: 106A, 621.

27 Jacobs DG, Haka-Ikse K, Wesson DE. Growth and development in patients operated on for islet cell dysplasia. F Pediatr Surg 1986; 21: 1184-9.

28 Schonau E, Deeg KH, Huemmer HP, Akcetin YZ, Bohles HJ. Pancreatic growth and function following surgical treatment of nesidioblastosis in infancy. Eur $f$ Pediat 1991; 150: 550-3

29 Tanner JM, Whitehouse RH. Clinical longitudinal standards for height, weight, height velocity, weight velocity and stages of puberty. Arch Dis Child 1976; 51: 170-9.

30 Illingworth RS, ed. The normal course of development. In: The normal child. 10th Ed. Edinburgh: Churchill Livingstone, 1991: 127-208.

31 Illingworth RS. Development of the infant and young child, normal and abnormal. 9th Ed. Edinburgh: Churchill Livingstone, 1987.

32 Illingworth RS. Basic developmental screening. 5th Ed. Oxford: Blackwell, 1990.

33 Taylor E. Psychological appraisal of children with cerebral defects. Cambridge, MA: Harvard University Press, 1961.
34 Greulich WW, Pyle SI, eds. Radiolographic atlas of skeletal development of the hand and wrist. 2nd Ed. Stanford: Stanford University Press, 1959.

35 Weiss PAM. Prophylactic insulin in gestational diabetes. Obstet Gynecol 1988; 71: 951.

36 Salvesen DR, Brudenell JM, Snijders RJM, Ireland RM, Nicolaides KH. Fetal plasma erythropoetin in pregnancies complicated by maternal diabetes mellitus. Am $\mathcal{f}$ Obstet Gynecol 1993; 168: 88-94.

37 Bochner CJ, Medearia AC, Williams J, Castro L, Hobel CJ, Wade ME. Early trimester ultrasound screening in gestational diabetes to determine the risk of macrosomia and labour dystocia at term. Am $\mathcal{F}$ Obstet Gynecol 1987; 157: 703-8.

38 Fraser R. Diabetes in pregnancy. Arch Dis Child 1994; 71: F224-30.

39 Rappaport R. Fetal growth. In: Bertrand J, Rappaport R, Sizoneko PC, eds. Pediatric endocrinology. 2nd Ed. Baltimore: Williams and Wilkins, 1993: 175-84.

40 Fowden AL. The role of insulin in prenatal growth. $f$ Dev Physiol 1989; 2: 173-82.

41 Hill DJ, Hogg J. Growth factors and the regulation of pre and postnatal growth. In: Jones CT, ed. Perinatal endocrinology. Vol 3, No 3. Bailliere's clinical endocrinology and metabolism. Philadelphia: Bailliere Tindall, 1989; 3: 579-625.

42 Nishijima $M$. Somatomedin-C as fetal growth promoting factor and amino acid composition of cord blood in Japanese neonates. $\mathcal{F}$ Perinatal Med 1986; 14: 163-9.

43 Wang HS, Chard T. The role of insulin-like growth factor-I and insulin like growth factor binding protein-1 in the control of human fetal growth. $\mathcal{F}$ Endocrinol 1992; 132: $11-9$.

44 Basset NS, Oliver MH, Breier BH, Gluckmann PD. The effect of maternal starvation on plasma insulin like growth factor I concentration in the late gestation in ovine fetus. Pediatr Res 1990; 27: 401-4.

45 Vohr BR, Lipsitt LP, Oh W. Somatic growth of children of diabetic mother with reference to birth size. $\mathcal{f}$ Pediatr 1980; 97: 196-200.

46 Cloherty JP, Epstein MF. Metabolic disorders: maternal diabetes. In: Cloherty JP, Stark AR, eds. Manual of neonatal care. 3rd Ed. Boston: Little, Brown, 1991: 3-16.

47 Bentham J, Rodriguez-Arnao J, Ross RJM. Acquired growth hormone resistance in patients with hypercatabolism. Horm Res 1993; 40: 87-91.

48 Revhaug A, Mjaaland M. Growth hormone and surgery. Horm Res 1993; 40: 99-101.

49 Hynes MA, Van Wyk J, Brooks PJ, D'Ercole AJ, Jansen M, Lund PK. Growth hormone dependence on Lund PK. Growth hormone dependence on like growth factor-II messenger ribonucleic acids. Mol Endocrinol 1987; 1: 233-42.

50 Cohick WS, Clemmons DR. The insulin like growth factors. Annu Rev Physiol 1993; 55: 131-53.

51 Herington AC. Insulin-like growth factors: biochemistry and physiology. In: Robertson DM, Herrington AC, ed. Growth factors in endocrinology. Vol 5, No 4. Bailliere's
clinical endocrinology and metabolism. Philadelphia: Bailliere Tindall, 1994: 531-51.

52 Phillips LS, Vasslopoulou-Sellin R. Somatomedins. N Engl f Med 1980; 302: 371-6.

53 Brismar K, Fernqvist-Forbes E, Wahren J. Hall K. Effect of insulin on the hepatic production of insulin-like growth factor-binding protein-1 (IGFBP-1), IGFBP-3, and IGF-I in insulin dependent diabetes. F Clin Endocrinol Metab 1994; 79: 872-8.

54 Glaser B, Hirsch HJ, Landau H. Persistent hyperinsulinemic hypoglycemia of infancy: long-term octreotide treatment without pancreatectomy. F Pediatr 1993; 123: 644-50.

55 Warden MJ, German JC, Buckingham BA. The surgical management of hyperinsulinism in infancy due to nesidioblastosis. F Pediatr Surg 1988; 23: 462-5.

56 Brockenbrough JS, Weir GC, Bonner-Weir S. Discordance of exocrine and endocrine growth following $90 \%$ pancreatectomy in the rat. Diabetes 1988; 37: 232-6.

57 Bonner-Weir S, Trent DF, Weir GC. Partial pancreatectomy in the rat and subsequent defect in glucose-infused insulin release. $\mathcal{F C l i n}$ Invest 1983; 71 : 1544-53.

58 Leibowitz G, Glaser B, Higazi AA, Salamah M, Cesari E, Landau $H$. Hyperinsulinemic hypoglycemia of infancy (nesidioblastosis) in clinical remission, high incidence of diabetes mellitus and persistent B-cell dysfunction at long-term follow-up. $f$ Clin Endocrinol Metab 1995; 80: 386-92.

59 Aynsley-Green A. Nesidioblastosis of the pancreas in infancy, Dev Med Child Neurol 1981; 23: 372-9.

60 Baker L, Stanley CA. Hyperinsulinism in infancy: a pathophysiologic approach to diagnosis and treatment. In: Chimmello G, Laron Z, eds. Recent progress in paediatric endocrinology. London: Academic Press, 1977: 89-100.

61 Cornblath $M$, Schwartz $R$. Hypoglycaemia in the neonate. In: Schaffer AJ, Markowitz M, eds. Disorders of carbohydrate metabolism in infancy. 2nd Ed, Vol 3. Major problems in clinical pediatrics series. Philadelphia: Saunders, 1976: in clinical

62 Anonymous Brain damage by neonatal hypoglycaemia [Editorial]. Lancet 1989; i: 882-3.

63 Illingworth RS. Basic developmental screening. 5th Ed. Oxford: Blackwell, 1990.

64 Wieloch T. Hypoglycaemia-induced neuronal damage prevented by an N-methyl-D-aspartate antagonist. Science 1985; 230: 681-3. 
65 Choi DW. Glutamate neurotoxicity and diseases of the nervous system. Trends Neurosci 1988; 11: 465-9.

66 Siesjo BK, Bengtsson F. Calcium fluxes, calcium antagonists, and calcium related pathology in brain ischemia hypoglycemia and spreading depression: a unifyin hypothesis. F Cereb Blood Flow Metab 1989; 9: 127-40

67 Arkai N, Greenberg JH, Sladky JT, Uematsu D, Karp A Reivich $M$. The effect of hyperglycemia on intracellular calcium in stroke. F Cereb Blood Flow Metab 1992; 12: 469-76.

68 Meldrum B, Garthwaite J. Excitatory amino acid neurotoxicity and neurodegenerative disease. Trends Pharmacol Sci 1990; 11: 379-87.

69 Auer RN. Progress review: hypoglycemic brain damage. Stroke 1986; 17: 699-708.
70 Young AB, Fagg GE. Excitatory amino acid receptor in the brain: membrane binding and receptor autoradiographi

71 Papagapiou MP, Auer RN. Regional neuroprotective effects of the NMDA receptor antagonist MK-801 (dizocilpine) in hypoglycemic brain damage. $\boldsymbol{f}$ Cereb Blood Flow Metab 1990; 10: 270-6.

72 Pizzi M, Ribola M, Valerio A, Memo M, Spano PF. Various $\mathrm{Ca} 2+$ entry blockers prevent glutamate-induced neurotoxicity. Eur $\mathcal{F}$ Pharmacol 1991; 209: 169-73.

73 Snyder EY, Cloherty JD. Perinatal asphyxia. In: Cloherty JD, Stark AR, eds. Manual of neonatal care. 3rd Ed. Boston: Little, Brown, 1991: 393-411.

\section{Surgery for drooling}

Drooling is said to be a problem in between 10 and $37 \%$ of children with cerebral palsy. It is messy, often unsightly, and sometimes smelly. It causes chronic irritation of facial skin, adds to the burden of care, and may cause embarrassment and loss of self esteem.

The ins and outs of surgical treatment have been debated for some years. Surgical options include, alone or in combination, removal of salivary glands, ligation of salivary ducts, transposition of salivary ducts, and division of salivary gland nerve supply.

In Victoria, Australia, the favoured procedure has been transposition of the submandibular ducts into the tonsillar fossas and ligation of one parotid duct (Kerri-lyn Webb and colleagues, Developmental Medicine and Child Neurology 1995; 37: 755-62). Thirty nine patients underwent the operation: 31 with cerebral palsy, four with neurological impairment of other cause, and four with intellectual disability without motor impairment.

Judging solely by preoperative and postoperative measures of drooling the results over six years of follow up were good with between 77 and $100 \%$ of patients showing improvement on various measures. Nevertheless $38 \%$ had 'moderate to severe' or worse drooling after the operation and in only $23 \%$ was postoperative drooling absent or mild. Twelve patients said that surgery had not helped them. Eighteen said their saliva had become thicker and 20 frothier and some found this distressing. There may have been an increase in dental caries and minor infections after the operation and five patients needed further surgery for ranulas. Nine complained of a dry mouth with crusting of the lips and two had airway obstruction leading in one to intubation and admission to intensive care.

In the same issue of Developmental Medicine and Child Neurology there is an editorial written by the president of the American Academy for Cerebral Palsy and Developmental Medicine calling for better outcome assessments and including the statement, 'We must listen to our patients to determine the kinds of outcomes that are important to improve the quality of their lives'. Yes, indeed.

ARCHIVIST 